\title{
Os lugares da sociologia na formação de estudantes do ensino médio: as perspectivas de professores*
}

Kelly Cristine Corrêa da Silva Mota

Faculdades de Taquara, Rio Grande do Sul

Escola Estadual de Ensino Médio Farroupilha

\section{Introdução}

Ainda que os esforços para a implantação da sociologia na escola brasileira sejam antigos, remontando a fins do Império, e os interesses por esse mo-

* Desde Benjamim Constant, passando por Florestan Fernandes e Antonio Candido, até o final dos anos de 1980 e ainda atualmente, em eventos acadêmicos e científicos tem prevalecido a defesa pela sociologia, ainda que a intenção seja formar os estudantes também com conteúdos da antropologia e da ciência política. Costa Pinto, num texto de 1956, por ocasião do I Seminário Sul-Americano de Ensino Superior em Ciências Sociais, refere-se ao ensino das ciências sociais. Os Parâmetros Curriculares Nacionais para o Ensino Médio (PCNEM) igualmente indicam esse termo ao longo dos seus textos, assim como também nomeiam separadamente as três ciências. A atual Lei de Diretrizes e Bases da Educação Nacional (LDB), por sua vez, denomina “conhecimentos de sociologia”. Em minhas leituras e pesquisas não encontrei um motivo especial para o destaque da sociologia. Pessoalmente, por ora, faço uso desse termo exatamente porque é o que figura em programas escolares, editais de contratação de professores e nos poucos estudos que existem sobre o assunto. vimento sejam permanentes no ideário educacional, poucas vezes ela tem sido objeto de análise por parte de estudiosos tanto das ciências sociais quanto da educação. O ensino da sociologia, especialmente no nível médio, requer uma maior atenção da que tem recebido, como sustenta Giglio:

\footnotetext{
[...] principalmente pelo fato de se verificar que as intenções e tentativas da sua inclusão no sistema educacional brasileiro acabaram por assumir uma certa permanência no ideário dessa ciência social no Brasil, a ponto de percorrer todo este século até obter alguns novos êxitos nos dias atuais. (Giglio, 1999, p. 1)
}

Interessar-se pelo ensino de uma ciência, afirmou certa vez Costa Pinto (1944) ao referir-se ao ensino das ciências sociais no Brasil nos anos de 1940, é importar-se pelo modo como essa ciência subsiste "de modo útil, desenvolvendo-se e exercendo sua plena função cultural" (p. 15). Atualmente, investigar e discutir a sociologia no ensino médio é de especial relevância para a percepção do seu processo de construção e instituição na escola, e também da sua recep- 
ção social, seja pelos alunos, pais ou professores. Debruçar-se sobre esse tema a partir das perspectivas de professores, no atual estágio da sua incipiente constituição como disciplina escolar, ${ }^{1}$ permite-nos perceber o imaginário e as expectativas que existem e que tem sido difundidas a respeito de sua especificidade e de sua importância (ou não) na educação escolar dos estudantes.

Acredito, como Arroyo (2000, p. 152), que "a escola não se define basicamente como um lugar de falas, mas de práticas, de afazeres". Contudo, nesse momento histórico de constituição da sociologia como conhecimento escolar, as falas dos professores revelam intenções e perspectivas, apresentando-se como dimensão importante na configuração das suas práticas. Nesse sentido, estabeleci como recorte central de análise, na pesquisa da qual resultou este artigo, a perspectiva de professores de sociologia no ensino médio a respeito do lugar dessa ciência na formação escolar dos estudantes. Por que, afinal, luta-se pela sua presença na escola? Por que se afirma sua relevância na formação dos estudantes?

Penso em educação e formação no âmbito da educação-formação humana, sobretudo a partir das reflexões de Paulo Freire, Miguel Arroyo e Moacir Gadotti. Essa noção vincula-se a processos globais da formação do ser humano, cujos objetivos e características ultrapassam a idéia estreita de ensino - sistematização de conhecimentos e transmissão de conteúdos escolares. É central nela "ter o ser humano e sua humanização como problema pedagógico" (Arroyo, 2000, p. 14). Em Paulo Freire busco amparo para pensar educação como libertadora e problematizadora. Assim, "além de um ato de conhecimento, a educação é também um ato político" (Freire, in Freire \& Shor, 1986, p. 25).

${ }^{1}$ Utilizarei indistintamente os termos "disciplina" e "componente curricular", a fim de não dividir o texto em discussões que por ora são menores. Com elas refiro-me às disciplinas escolares que constam dos planos de ensino do nível médio, tributárias das disciplinas acadêmicas e das diferentes ciências, mas com características e dinâmicas próprias em relação a estas.
[...] como experiência especificamente humana, a educação é uma forma de intervenção no mundo. Intervenção que além do conhecimento dos conteúdos bem ou mal ensinados e/ou aprendidos implica tanto o esforço de reprodução da ideologia dominante quanto o seu desmascaramento. (Freire, 1996, p. 110, grifos do original)

Gadotti (2000), inspirando-se fortemente em Freire, igualmente explicita essa perspectiva quando observa que, "apesar das dificuldades encontradas, o educador pode ainda ensinar não só a ler e escrever, mas ensinar a falar. Ensinar a falar, a gritar, que é o papel político do educador" (p. 148). Arroyo, no mesmo contexto teórico, salienta educação a partir da noção de direito e insiste no que ele chama de concepção alargada de educação:

\footnotetext{
[...] a escola não é o único espaço de formação, de aprendizado e de cultura. O fenômeno educativo acontece em outros espaços e tempos sociais, em outras instituições, nas fábricas, nas igrejas e terreiros, nas famílias e empresas, na rua e nos tempos de lazer, de celebração e comemoração, no trabalho [...] a educação acontece de formas muito diferenciadas. (Arroyo,1998, p. 147)
}

Sua concepção alargada e universal de educação refere-se à ampliação do entendimento dessa prática para além da escola e do fenômeno educativo, em diferentes e múltiplos processos sociais. Para ele, "universal não apenas no sentido de para todos, mas de dar conta da universalidade, pluralidade, omnilateralidade das dimensões humanas e humanizadoras a que todo indivíduo tem direito por ser e para ser humano" (idem, p. 155).

Evidentemente que, em razão da temática deste texto estar atrelada à escola, ao tratar de um componente curricular, por vezes pode parecer que restrinjo educação e formação a práticas que ocorrem na esfera escolar. Essas práticas de aprendizado e socialização, porém, são constituídas, influenciadas e potencializadas por processos sociais mais amplos que marcam professores, funcionários, pais e estudantes. Em virtude disso, a escola cotidianamente entrecor- 
tada por interesses e relações de poder diversas. Longe de refletir harmonia, a escola

[...] é simultaneamente reprodução das estruturas existentes, correia de transmissão da ideologia oficial; mas também ameaça à ordem estabelecida e possibilidade de libertação. A escola é uma instabilidade, mais ou menos aberta, a nossa ação. (Gadotti, 2000, p. 150)

O ensino da sociologia é posto, então, num ambiente que, a despeito das mais nobres intenções de formar adolescentes e jovens numa perspectiva de enfrentamento com a realidade social, como têm sugerido os argumentos mais freqüentes a seu favor, contém em si tanto possibilidades de uma "visão harmoniosa do mundo", na qual não há questionamentos sobre os fundamentos da ordem social (Gadotti, 2000, p. 151), quanto de uma educação emancipadora, tendência que, ao contrário, busca justamente compreender e transformar a ordem social injusta para as maiorias sociais.

Em um momento em que os esforços se voltam para a defesa da obrigatoriedade da sociologia no ensino médio, é um desafio problematizar idéias recorrentes em torno do seu lugar na formação dos estudantes. Profissionais e acadêmicos da área mobilizam-me e argumentam a favor do seu ensino, a fim de que ela tenha um espaço "garantido" nos programas escolares. Entretanto, é preciso, justamente, suspeitar e investigar algumas implicações de práticas e concepções que se cristalizam no tempo. Esse, acredito, é um dos objetivos da prática da pesquisa e da produção do conhecimento. Minha proposta neste artigo não é esvaziar os significados mais caros da área, mas provocar reflexões sobre o assunto e convidar para que desvendemos os fundamentos de nossas próprias convicções, com a finalidade de termos um pouco de clareza sobre o sentido da presença da sociologia no ensino médio e na vida dos estudantes, e do trabalho de professores na área.

\section{Algumas informações metodológicas}

As problematizações aqui apresentadas emergem da análise de questionários e entrevistas semi-estru- turadas realizadas com professores que, independente da formação universitária e do vínculo profissional com as escolas em que trabalham, ${ }^{2}$ ministram sociologia no ensino médio em escolas estaduais do Rio Grande do Sul.

Parte dos professores com os quais conversei (cinco, de um total de doze pessoas que forneceram os elementos empíricos para a pesquisa) foram meus colegas em um curso de extensão sobre o ensino da sociologia para professores do ensino médio, realizado na Universidade Federal do Rio Grande do Sul (UFRGS), no ano de 2001. Dentre uma média de trinta pessoas que freqüentavam o curso, eles foram escolhidos por estarem lecionando sociologia naquele momento, em diferentes cidades: Porto Alegre, Gravataí, São Leopoldo, Guaporé, Portão. Não foi possível continuar e aprofundar a pesquisa empírica com esses professores em razão do término do referido curso.

As questões diziam respeito às práticas em sala de aula e às justificativas da importância da sociologia na formação dos estudantes. Eram elas:

a) Qual o papel da sociologia na formação dos seus alunos?

b) Quais são suas metodologias de aula?

c) Quais suas formas de avaliação da aprendizagem dos estudantes no que diz respeito à cidadania, reflexão e crítica?

Esse levantamento exploratório careceu de pormenores que dessem conta da compreensão das concepções que tinham os professores a respeito de tais temas, bem como de elementos que porventura con-

${ }^{2}$ Muitos professores de escolas estaduais trabalham em regime de contratação emergencial, podendo ser estudantes de cursos afins às disciplinas que lecionam. Na pesquisa que empreendi, a grande maioria era de concursados, graduados nos cursos de ciências sociais, pedagogia, filosofia e história, ministrando sociologia (ver quadros 1 e 2). Ainda assim, a assunção de períodos de aula dessa disciplina servem, com frequiência, para completar a carga horária dos docentes. Essa também é a situação de disciplinas como educação artística, ensino religioso, filosofia e psicologia. 
duziam suas reflexões e argumentações naquele sentido. Tendo em vista essa necessidade, procedi à reformulação do roteiro de entrevistas, incluindo questões sobre o perfil docente, a situação atual da sociologia na legislação, concepções de educação, referencial teórico de formação e de trabalho, entre outras. Além disso, procurei conduzir as entrevistas de forma aberta, de modo que seguidamente me valia das singularidades de respostas e justificativas para formular outras questões, não necessariamente presentes no roteiro.

Passei, então, à fase da pesquisa que denominei de "aprofundamento da dimensão empírica". De maneira pontual, nesse momento pretendi observar a recorrência ou não dos argumentos e expectativas dos entrevistados, introdutoriamente percebidos nos questionários. A recorrência dos argumentos nessa segunda fase da pesquisa ficou por conta das idéias de cidadania e de crítica, que serão problematizadas adiante.

Para aprimorar a dimensão empírica do estudo, busquei escolas estaduais gaúchas de ensino médio, cujas grades curriculares contemplassem a sociologia. Esse foi o primeiro passo para logo encontrar e convidar professores que ministrassem essa disciplina para participar da pesquisa. Fixei, então, minhas buscas nas cidades de Porto Alegre e Viamão, em virtude da facilidade de acesso. Viamão, no entanto, tem uma justificativa extra: além de ser a cidade onde atuo como professora de sociologia, observei nos dois últimos concursos públicos para o magistério estadual (1999 e 2001) que é uma das poucas que ofereceu vagas para essa disciplina. Havia, nessa cidade, na época de minha pesquisa, um movimento singular de inclusão da sociologia nas escolas. Presentemente, editais de abertura de inscrição e seleção de professores da Secretaria da Educação do Estado indicam ampliação desse movimento em várias cidades gaúchas. ${ }^{3}$

${ }^{3}$ Professores e diretoras de diferentes escolas de Viamão não apontaram nenhum motivo especial para a situação que observei em relação à inclusão da sociologia nessa cidade. Baseados na LDB e nos PCNEM, eles estabeleceram uma nova orientação curricular que a inclui. Muito provavelmente, a própria refe-
A opção por escolas estaduais justifica-se pela importância das mesmas do ponto de vista social: recebem atualmente grandes contingentes de jovens das camadas populares. Nesse espaço social, as propostas da sociologia atingiriam muitos deles. Quanto ao nível de ensino, limitei-me a entrevistar professores do ensino médio porque é o segmento que concentra as atenções dos envolvidos nas discussões sobre o retorno da sociologia à escola. Também é o nível para o qual a disciplina é sugerida na Lei de Diretrizes e Bases da Educação Nacional (LDB) e nos Parâmetros Curriculares Nacionais do Ensino Médio (PCNEM), constituindo-se, desse modo, no espaço mais provável para abrigá-la.

Os quadros 1 e 2 caracterizam os professores entrevistados segundo a formação universitária e algumas informações profissionais. O quadro 1 refere-se aos professores que responderam os questionários. $\mathrm{O}$ quadro 2 contém dados dos entrevistados da fase de aperfeiçoamento; possui questões que não foram formuladas ou captadas no momento exploratório. ${ }^{4}$

O número dos sujeitos da pesquisa totalizou, como já referi, doze professores, considerando-se o estudo exploratório e o momento posterior. No primeiro foram cinco entrevistados, e no segundo, sete. Doze entrevistados é uma quantidade expressiva para proceder a uma análise, dado o retorno bastante recente da sociologia à escola e, conseqüentemente, a dificuldade de encontrar instituições que a ofereçam.

rência à matéria nesses dois documentos tenha inspirado sua incorporação aos programas escolares. Quanto à inclusão da sociologia na grade curricular em outras cidades gaúchas, o último edital que inscreveu para concurso do magistério estadual, de janeiro de 2005, relaciona 216 cidades que necessitam de professores para docência na área, número expressivo para uma disciplina não-obrigatória e que em tempos anteriores quase não figurava em concursos e contratações do magistério. Em dezembro de 2003, um edital para contratação emergencial de professores relacionou em torno de 80 cidades cujas escolas necessitavam de professores de sociologia.

${ }^{4}$ Os nomes dos professores entrevistados são fictícios; os do quadro 1 responderam ao questionário em junho de 2001; os do quadro 2 foram entrevistados ao longo de 2002. 
A rigor, o relevante para os meus interesses de pesquisa foi o conteúdo das falas dos entrevistados, que me permitiu perceber e compreender as expectativas de professores sobre o lugar daquela disciplina na formação escolar dos estudantes.

\section{Quadro 1}

\begin{tabular}{|l|l|l|}
\hline Entrevistado & \multicolumn{1}{|c|}{$\begin{array}{c}\text { Formação } \\
\text { universitária }\end{array}$} & $\begin{array}{c}\text { Tempo como professor } \\
\text { de sociologia }\end{array}$ \\
\hline Rodrigo & Ciências sociais & Desde março de 2001 \\
\hline Vera & História & Desde março de 2001 \\
\hline Pedro & Ciências sociais & 3 anos \\
\hline Rafaela & Pedagogia & 10 anos \\
\hline Francisco & Ciências sociais & 7 meses \\
\hline
\end{tabular}

\section{A sociologia no ensino médio}

A sociologia, depois de tanto tempo fora das recomendações legais, volta a figurar na lei máxima da educação e em alguns programas escolares. No entanto, afora a sociologia da educação, que há muito é ministrada no curso normal (magistério de nível médio), a sociologia no ensino médio é uma área "nova" na escola e com escassa produção científica. Digo "nova" porque é uma disciplina cuja trajetória na escola é relativamente recente, datando de 1925, ano em que pela primeira vez foi oferecida obrigatoriamente nos currículos escolares brasileiros, introduzida pela Reforma Rocha Vaz. Ademais, ainda ocupa um lugar marginal no rol dos componentes curricula-

\section{Quadro 2}

\begin{tabular}{|c|c|c|c|c|c|}
\hline \multirow[b]{2}{*}{ Entrevistado } & \multirow[b]{2}{*}{$\begin{array}{c}\text { Formação } \\
\text { universitária }\end{array}$} & \multicolumn{4}{|c|}{ Perfil docente } \\
\hline & & $\begin{array}{l}\text { Tempo total } \\
\text { de exercício } \\
\text { no magistério }\end{array}$ & $\begin{array}{l}\text { Tempo como } \\
\text { professor de } \\
\text { sociologia }\end{array}$ & $\begin{array}{l}\text { Carga horária } \\
\text { semanal de trabalho } \\
\text { na sociologia }\end{array}$ & $\begin{array}{l}\text { Outras disciplinas que lecionou ou leciona } \\
\text { no tempo total de magistério }\end{array}$ \\
\hline Flávia & $\begin{array}{l}\text { História } \\
\text { Pedagogia }\end{array}$ & 17 anos & $\begin{array}{l}\text { Desde março } \\
\text { de } 2002\end{array}$ & $\begin{array}{l}2 \text { períodos } \\
\text { (1 período por turma) }\end{array}$ & $\begin{array}{l}\text { Filosofia, Psicologia, História, Geografia, } \\
\text { Religião, Séries Iniciais }\end{array}$ \\
\hline Décio & Filosofia & 32 anos & 4 anos & $\begin{array}{l}8 \text { períodos } \\
(2 \text { períodos por turma) }\end{array}$ & $\begin{array}{l}\text { Filosofia, Filosofia da Educação, História, Re- } \\
\text { ligião, Psicologia, Psicologia das Relações Hu- } \\
\text { manas, OSPB*, Educação Artística, Geogra- } \\
\text { fia, Física, Moral e Cívica, Direito e Legislação }\end{array}$ \\
\hline Luíza & Pedagogia & 17 anos & $\begin{array}{l}\text { Desde setembro } \\
\text { de } 2002\end{array}$ & $\begin{array}{l}5 \text { períodos } \\
\text { (1 período por turma) }\end{array}$ & $\begin{array}{l}\text { Séries Iniciais, Psicologia da Educação, } \\
\text { Educação, Filosofia da Educação, Didática, } \\
\text { Psicologia }\end{array}$ \\
\hline Amanda & História & 1 ano & 1 ano & $\begin{array}{l}6 \text { períodos } \\
\text { ( } 2 \text { períodos por turma) }\end{array}$ & $\begin{array}{l}\text { Religião, Educação Artística, Filosofia, } \\
\text { História }\end{array}$ \\
\hline Cleonice & $\begin{array}{l}\text { Ciências } \\
\text { Sociais }\end{array}$ & $\begin{array}{l}\text { Desde junho } \\
\text { de } 2002\end{array}$ & $\begin{array}{l}\text { Desde junho } \\
\text { de } 2002\end{array}$ & $\begin{array}{l}11 \text { períodos } \\
\text { ( } 2 \text { períodos em cada } \\
\text { turma noturna, e } 1 \\
\text { período em cada } \\
\text { turma diurna) }\end{array}$ & Educação Artística \\
\hline Eliana & Pedagogia & 19 anos & $\begin{array}{l}\text { Desde março } \\
\text { de } 2002\end{array}$ & $\begin{array}{l}4 \text { períodos } \\
(2 \text { períodos por turma })\end{array}$ & História, Psicologia, Séries Iniciais \\
\hline Paula & Pedagogia & 20 anos & 8 anos & $\begin{array}{l}6 \text { períodos } \\
\text { ( } 2 \text { períodos por turma) }\end{array}$ & $\begin{array}{l}\text { Filosofia } \\
\text { Atividade profissional principal no } \\
\text { Setor de Coordenação Pedagógica }\end{array}$ \\
\hline
\end{tabular}

* Organização Social e Política do Brasil (OSPB) 
res, figurando com pouca carga horária ou tendo seus conteúdos diluídos em outras ciências humanas, ou ainda como integrante do conjunto de práticas e disciplinas da parte diversificada ${ }^{5}$ do currículo, o que possivelmente a impede de conquistar e solidificar seu espaço numa estrutura de ensino ainda majoritariamente disciplinar. Quanto à produção científica recente, raros são os trabalhos que tematizam o assunto. ${ }^{6}$

A rigor, foi em 1891 que pela primeira vez foi referida e proposta numa reforma educacional, qual seja, a do Governo Provisório da República, que estabeleceu sua obrigatoriedade no ensino secundário. Coordenada por Benjamin Constant, à época ministro da Instrução Pública, essa reforma foi apenas em parte operacionalizada, pois dispositivos legais modificaram a organização curricular que propunha. Dessa forma, o decreto $\mathrm{n}^{\circ} 3.890$, de $1^{\circ}$ de janeiro de 1901 (Reforma Epitácio Pessoa), desobrigou o ensino de sociologia, sem que de fato ela tenha sido ofertada (Santos, 2002).

${ }^{5}$ Os ensinos médio e fundamental brasileiros, a partir da lei $n^{\circ} 9.394 / 96$, passam a estruturar-se segundo uma base nacional comum e uma parte diversificada. A LDB não refere nominalmente disciplinas, mas seu artigo 26 indica o ensino obrigatório de "estudos da língua portuguesa e da matemática, o conhecimento do mundo físico e natural e da realidade social e política, especialmente do Brasil, o ensino da arte [...] de forma a promover o desenvolvimento cultural dos alunos, e a educação física, integrada à proposta pedagógica da escola”. A parte diversificada, por sua vez, inclui disciplinas, projetos, módulos, enfim, diversificadas experiências escolares, que expressem necessidades e interesses regionais e locais relacionados com a base nacional comum. A sociologia compor essa dimensão não significa que ela está numa condição inferior em relação às disciplinas já tradicionais nos programas (português, matemática, história...), mas, diante da gama de possibilidades para a construção da parte diversificada e da autonomia dos estabelecimentos escolares para definirem-na, suas chances de participar da grade curricular certamente são abreviadas.

${ }^{6}$ Cf. Corrêa (1993), Giglio (1999), Meucci (2000), Mota (2003), Santos (2002).
Por volta das décadas de 1920 e de 1930, sobretudo, sociólogos brasileiros estiveram envolvidos não somente em debates a respeito da sociologia no ensino secundário, como também assumiram cargos administrativos e docentes, e incentivaram o retorno da disciplina a esse nível do ensino. Assim, por exemplo, Delgado de Carvalho assumiu a reforma no Colégio Pedro II em 1925, incluindo a sociologia. Carneiro Leão, como secretário na reforma educacional de Pernambuco em 1929, fez o mesmo. Fernando Azevedo, como diretor geral de instrução pública do Distrito Federal e de São Paulo, entre 1927 e 1933, também teve contribuição importante nesse período ao integrar a sociologia aos cursos normal e secundário. O interesse pelo assunto continuou nas décadas de 1940 e de 1950, e a proposta dessa ciência como fundamental na formação de jovens brasileiros vai, a partir de então, com as primeiras escolas superiores de sociologia, estar presente nas produções intelectuais de sociólogos brasileiros, tais como Luiz Costa Pinto e Florestan Fernandes.

Como revela Meucci (2000), no período de 1931 a 1941 o conhecimento sociológico é parte das matérias exigidas para os exames de admissão aos cursos superiores. Assim, os alunos candidatos às faculdades de direito, engenharia, arquitetura, química e medicina assistiam a aulas de sociologia nos cursos complementares, que duravam dois anos após o término do ensino secundário, a fim de se preparar para as provas de admissão. Os candidatos às vagas de direito tinham quatro horas semanais de aula de sociologia, ao passo que os candidatos aos outros cursos referidos assistiam a três horas semanais de aula da matéria.

Incluída nos cursos complementares num momento em que o ensino secundário passara a ser responsabilidade da União, a sociologia integrou um movimento reformador que pretendia substituir a educação clássica por uma educação moderna. “A rigor os reformadores pretendiam, com a eliminação de disciplinas como a língua latina, fundar um novo programa em que o conhecimento oferecido fosse, de fato, aplicável às necessidades do mundo moderno" 
(Meucci, 2000, p. 57). Os conhecimentos científicos, desse modo, deveriam estar ao alcance de todos, daqueles que se convencionou chamar "homens médios" - os jovens da elite brasileira -, e não apenas de especialistas, a fim de auxiliar no bem-estar da sociedade e na resolução dos problemas sociais. A intenção, nesse contexto social e educacional, era que a sociologia contribuísse na

[...] formação de jovens com a capacidade de investigar e propor soluções para os problemas nacionais. Esses jovens imbuídos de um caráter científico e prático conduziriam as transformações da realidade brasileira. Tratava-se, portanto de um projeto de constituição de uma nova elite dirigente. Projeto no qual a sociologia teria um papel fundamental. Por isso, a presença dessa disciplina nos cursos complementares e no curso normal, visto que nesses cursos se iniciava a formação dos futuros advogados, arquitetos, engenheiros, médicos e professores. (Santos, 2002, p. 4)

Contudo, o conhecimento sociológico "não chegara nem ao operário, nem ao homem de rua" (Meucci, 2000, p. 61), uma vez que, se atentarmos para a época em questão, final dos anos de 1930 e década de 1940, e se nos reportarmos ainda ao final do século XIX, o ensino secundário brasileiro atendia fundamentalmente a "uma elite, pois era composta por aqueles poucos que se destinavam às faculdades" (Giglio, 1999, p. 5). Meucci (2000) compartilha e enriquece essa informação afirmando que no Brasil, em 1939, existiam 629 instituições de ensino secundário, das quais 530 eram particulares.

Em 1942 começa o longo período em que a sociologia ficará ausente dos currículos como disciplina obrigatória. A reforma de 1942, de Gustavo Capanema, ministro da educação do governo de Getúlio Vargas, desobrigou o ensino de sociologia nas escolas secundárias, definido pela Reforma Rocha Vaz em 1925, mantendo-o somente nas escolas normais. Pela Reforma Gustavo Capanema o ensino secundário foi organizado em dois ciclos: o ginasial, um curso de quatro anos, e o colegial, subdividido em dois cursos de três anos cada: o curso científico e o curso clássi- co. O primeiro destinava-se ao estudo das ciências, e o segundo, à formação intelectual. Com a intenção de desatrelar o ensino secundário do ensino universitário, a reforma de Capanema extinguiu os cursos complementares que preparavam para as carreiras superiores. O ensino da sociologia, então, perdeu a obrigatoriedade, visto que a disciplina era tida como preparatória para as carreiras de direito, medicina e engenharia (Santos, 2002, p. 5-6).

A partir de 1964, em virtude da nova orientação política que passa a dirigir o país, as intervenções e propostas para o sistema escolar passaram a priorizar a formação profissionalizante. Não somente a sociologia, mas também a filosofia e as ciências humanas de maneira geral foram retiradas do ensino secundário. Em 1971, a lei $\mathrm{n}^{\circ} 5.692$, denominada Reforma Jarbas Passarinho, modifica a organização estrutural estabelecida pela Reforma Capanema. Assim, os primeiros oito anos de estudo, incorporando o primário e o ginasial, denominados de "primeiro grau", era obrigatório para estudantes na faixa etária de sete a quatorze anos. O "segundo grau", com três anos de duração, substituiu o ensino colegial nas suas diferentes divisões (científico, clássico, normal e técnico). Nesse nível, os jovens deveriam ter uma habilitação profissional. A sociologia, apesar de compor a parte diversificada desse curso, teve suas possibilidades de reinserção diminuídas, pois "as escolas eram orientadas no sentido de incluírem disciplinas que implicassem aplicação prática dos conteúdos estudados" (idem, p. 7).

O período de reinserção da sociologia no segundo grau vai de 1982 até os tempos atuais. O movimento de transformações socioeconômicas e políticas, principalmente pela redemocratização do Brasil em fins da década de 1970, estimulou reformulações no sistema escolar. Assim, a lei $n^{\circ} 5.892 / 71$ foi alterada pela lei $\mathrm{n}^{\circ} 7.044 / 82$, que retirou a obrigatoriedade de profissionalização do segundo grau e a substituiu por um conceito mais genérico: o de "preparação para o trabalho". Por essa lei, abriram-se também espaços para a introdução de disciplinas optativas. Entretanto, sem recursos humanos e materiais para a con- 
cretização da proposta, dificilmente se considerava a inclusão dessas disciplinas.

Em 1986, a resolução $n^{\circ} 6$ do Conselho Federal de Educação (CFE) recomendou o ensino da filosofia no segundo grau como parte do núcleo comum de disciplinas de dois tipos de cursos nesse nível de ensino: o voltado para a formação geral e o profissionalizante. A sociologia, nesse contexto, figura novamente como possibilidade na parte diversificada do currículo, a exemplo do que ocorrera em 1971, com a Reforma Jarbas Passarinho. Esse é um importante momento de revitalização dessa ciência, dadas as perspectivas de redemocratização política do país.

\footnotetext{
[...] a partir de então, educadores, políticos, sociólogos e estudantes em vários estados intensificaram as lutas pela sociologia no ensino médio. Em São Paulo, ainda em 1983, a Associação dos Sociólogos promove a mobilização da categoria em torno do "Dia Estadual de Luta pela volta da Sociologia ao $2^{\circ}$ Grau", ocorrido em 27 de outubro de 1983. Em decorrência desse movimento, a secretaria de educação do estado ofereceu cursos de atualização para docentes da disciplina, e em 1986 realizou concurso público para professores de sociologia. (Santos, 2002, p. 9)
}

Em Minas Gerais ocorreu igualmente um movimento a favor do retorno da sociologia ao segundo grau. Em virtude disso, as escolas públicas estaduais e municipais desse estado incluíram-na de forma obrigatória em 1990. No Distrito Federal, ela passou a compor a grade de matérias do segundo grau em 1985. O primeiro concurso público para a área nessa localidade ocorreu em 1987. Em 1989, em razão das discussões no Congresso Nacional do projeto da nova LDB, intensificaram-se as lutas acerca desse retorno.

Em decorrência dessas reivindicações, o projeto (de LDB) aprovado na Câmara Federal em 1993 continha uma emenda do deputado Renildo Calheiros, do PCdoB (Partido Comunista do Brasil) de Pernambuco, que tornava o ensino de sociologia obrigatório no $2^{\circ}$ Grau. Todavia, no Senado Federal, o substitutivo Darcy Ribeiro derrubou a proposta (Santos, 2002, p. 9).
Após algumas negociações na Câmara Federal, na qual o assunto voltou a ser discutido, a sociologia foi referida na lei máxima atual do sistema de ensino brasileiro, promulgada em 1996. Ainda assim, ela é apenas sugerida, juntamente com a filosofia, como elemento importante para o exercício da cidadania; não é, portanto, disciplina obrigatória, mas apenas uma das possibilidades (atividades, projetos, outras disciplinas) para compor a parte diversificada da grade curricular do ensino médio.

Interessante observar que a referência à sociologia venha ligada à questão da cidadania. Como nos contam Santos (2002) e Maciel (1986), o interesse por temas sociológicos, especialmente tendo como eixo a cidadania e a democracia, advém do contexto de redemocratização política do país no final da década de 1970. Tal interesse foi percebido pela visibilidade crescente que tiveram os profissionais das ciências sociais. Dessa forma, eles

\footnotetext{
[...] começam a aparecer cada vez mais na televisão e na grande imprensa, como também participam de várias associações, como partidos políticos e sindicatos. A participação de antropólogos, cientistas políticos e sociólogos nesses espaços e na mídia visava atender às demandas de um público interessado em compreender temas como os movimentos sociais, as instituições políticas, a questão agrária, os movimentos culturais e a questão feminina. (Santos, 2002, p. 10)
}

No ano de 2001, o projeto de lei ( $\mathrm{n}^{\circ} 3.178-\mathrm{B}$, de 1997) que tornaria o ensino da sociologia e da filosofia obrigatórios no ensino médio, de autoria do deputado Padre Roque (Partido dos Trabalhadores do Paraná), foi vetado integralmente pelo presidente Fernando Henrique Cardoso. No Diário Oficial da União de 9 de outubro de 2001 foram publicadas as razões do veto: a proposta acarretaria ônus para os Estados na contratação de professores; e não haveria licenciados suficientes para atender às demandas das escolas, caso fosse aprovada.

Tais razões destoam das recomendações da atual LDB. Primeiro, porque a composição das áreas de conhecimento não implica aumento da carga horária se- 
manal ou anual. Os componentes curriculares podem simplesmente ser reorganizados dentro do tempo previsto. Em segundo lugar, quanto aos professores, a lei determina um tempo para que se habilitem em curso superior. No que se refere à demanda das escolas, não é possível afirmar a falta de profissionais, pois, como as escolas têm autonomia para determinar o tempo e a forma de organização de cada componente curricular, não se sabe de antemão as horas que seriam necessárias e destinadas à sociologia.

O projeto referido apresenta uma breve justificação para a obrigatoriedade do ensino da filosofia e da sociologia. O autor, deputado Padre Roque, cita Franklin Leopoldo e Silva:

A filosofia tem uma função de articulação do indivíduo enquanto personagem social se entendermos que o autêntico processo de socialização requer a consciência e o reconhecimento da identidade social e uma compreensão crítica da relação homem-mundo. 7 (Projeto de lei n ${ }^{\circ} 3.178-B, 1997$ )

Talvez defender a obrigatoriedade de uma disciplina também destoe das diretrizes legais e vá, até mesmo, na contramão da discussão atual sobre interdisciplinaridade. Contudo, é observando o primeiro parágrafo do artigo 26 da LDB que se compreende esse posicionamento. Diz o artigo:

Os currículos a que se refere o caput [do ensino fundamental e médio] devem abranger, obrigatoriamente, o estudo da língua portuguesa e da matemática, o conhecimento do mundo físico e natural e da realidade social e política, especialmente do Brasil. (Grifo do original)

O estudo da realidade social e política, que é um dos focos obrigatórios da LDB, certamente se beneficia do acúmulo de conhecimentos da sociologia. No entanto, esta é quase uma desconhecida dos estudan-

7 “As observações supra valem, mutatis mutandis, para a Sociologia". Essa frase finaliza a proposta do deputado Padre Roque, bem como estende a justificativa para a Sociologia. tes, dos pais dos estudantes e de muitos professores de outras áreas. A defesa pela sua obrigatoriedade dáse para garantir-lhe um espaço na escola, um espaço para que seus temas e discussões fundamentais cheguem aos estudantes.

A sociologia figurar como sugestão para compor o ensino médio já é um resultado positivo das lutas dos professores e envolvidos com a sua defesa na escola. Porém, nas condições em que é referida, tem suas possibilidades limitadas, uma vez que seus conteúdos podem ser diluídos em projetos interdisciplinares ou ainda em outras matérias. É a partir dessa realidade que sociólogos, estudantes, educadores e políticos retomam articulações e reivindicações pelo seu retorno obrigatório à escola. Nesse sentido, pressões por parte das coordenações de cursos das ciências sociais, de universidades, de sindicatos, e a realização de eventos acadêmicos e científicos que promovam o debate e a visibilidade em torno do tema, bem como o esforço pela aprovação de projetos que tornem a sociologia obrigatória, têm sido na atualidade o canal promotor das discussões a respeito da sua importância na formação dos jovens brasileiros. É um movimento ainda em processo.

\section{Sociologia para a cidadania e para a crítica}

Feita essa introdução a respeito da trajetória da sociologia na escola, focalizarei agora as justificativas dos professores sobre a presença dessa disciplina na formação dos estudantes.

De um modo geral, defensores do retorno da sociologia aos programas curriculares argumentam sua importância em razão de uma formação para a crítica e para a cidadania. As entrevistas, as leituras teóricas e os documentos legais indicam isso. Alguns professores que ministram aulas de sociologia no ensino médio assim definiram os lugares dessa ciência na formação dos estudantes:

\footnotetext{
[...] despertar os alunos para o seu papel de indivíduos cidadãos, buscando despertar neles uma visão crítica da sociedade, partindo da sua realidade. (Rose)
} 
[...] levar os alunos a uma reflexão e compreensão da sociedade em que estão inseridos; formar cidadãos conscientes; problematizar questões cotidianas; oportunizar espaços de discussão. (Vera) ${ }^{8}$

Em princípio, as falas referem-se a objetivos e características desejáveis e evidentes da sociologia e da própria função educativa da instituição escolar. Não obstante, como alerta Gentili (2000, p. 143) acerca da formação do sujeito democrático, que parece guardar proximidade com o sujeito crítico, cidadão, consciente de seus atos, a relação entre essas dimensões afigura-se evidente, a questão é "sobre quais fundamentos se define tal vínculo, que tipo de educação se relaciona com que tipo de cidadania, de sociedade, de justiça ou de democracia”. A reflexão de Gentili tem como pressuposto o fato de que os significados não são unívocos; somos nós que os modificamos, os deturpamos, os incrementamos, os compartilhamos ou não, enfim, os criamos. Como bem disse um professor entrevistado: “[...] sem dúvida o discurso da moda é a construção da cidadania” (Décio).

Educar para a cidadania tem sido uma proposta recorrente na voz de legisladores, educadores, políticos, empresários. Atualmente, apresenta-se como "uma das fontes de revitalização da importância da sociologia" (Meksenas, 1994, p. 17). Essa hipótese confirma-se na passagem de uma outra entrevista: "[...] eu acho que a sociologia é importante para o desenvolvimento da cidadania; para as pessoas saberem dos seus direitos e deveres" (Eliana). Ao mesmo tempo em que a entrevistada situa o lugar da sociologia como importante na formação do cidadão, o faz definindo a cidadania a partir da noção de "direitos e deveres". Ainda que breve, a frase suscita algumas questões relevantes para o que me propus a conhecer um pouco mais nessa pesquisa.

Mais do que "direitos e deveres", o dito acima fala da necessidade de as pessoas "saberem" da existência desses. Nesse sentido, pode-se pensar que a so-

${ }^{8}$ Citações de professores entrevistados durante a pesquisa referida no início do artigo. ciologia, por meio de seus conteúdos e conceitos, teria uma função informativa, possibilitando aos estudantes conhecerem os direitos e deveres dos quais são "possuidores". Essa é uma perspectiva reducionista da cidadania como mera condição legal, limitada ao nível institucional e formal. Como bem analisa Gentili (2000), "a educação, a partir desse enfoque, deveria ser vista como um mecanismo de difusão, de socialização e de reconhecimento dos direitos (civis, políticos e sociais) que definem o campo da cidadania” (p. 146).

Reconhecer direitos e deveres é uma dimensão importante na construção da cidadania, pois "a ignorância pode nos impedir de exercitar esse direito ou de reclamar por seu cumprimento" (idem, ibidem). Entretanto, mais do que uma definição jurídica e um "conteúdo" de sala de aula, cidadania implica valores e práticas que envolvem o cotidiano das pessoas. Esses valores e práticas fundamentam-se e constroemse em uma moralidade, cuja natureza é sempre historicamente condicionada.

Na mesma linha de pensamento, Dagnino (1994; Dagnino et al., 2000) enfatiza a dimensão cultural da cidadania, sobretudo em movimentos sociais, com base nos quais identifica uma ampliação do espaço político e, por isso, a emergência de sujeitos políticos de novo tipo, de um exercício cidadão de novo tipo, o que ela denomina uma nova cidadania. Assim, a luta por direitos e, sobretudo, pela criação deles, o direito à igualdade e o direito à diferença, emergentes das lutas dos movimentos sociais, justificariam falar de uma nova cidadania. Segundo ela, trata-se de

\section{[...] um projeto para uma nova sociabilidade: não somente a incorporação no sistema político em sentido estrito, mas um formato mais igualitário de relações sociais em todos os níveis, inclusive novas regras para viver em sociedade. (Dagnino et al., 2000, p. 88)}

Apesar dos ideais de cidadania e criticidade numa perspectiva de enfrentamento radical ${ }^{9}$ da realidade,

${ }^{9}$ A expressão radical refere-se à compreensão das raízes dos fenômenos sociais com o conseqüente desenvolvimento de 
recorrentes nas falas dos entrevistados, questões apontadas por uma professora traduzem alguns dos limites concretos e fortemente arraigados nas relações sociais escolares no desenvolvimento daquelas:

[...] nós temos professores que, além de usarem viseiras, se colocam num pedestal, e não admitem que o aluno lhe faça uma crítica. $O$ professor ainda não consegue fazer uma interrelação com o aluno; ele se coloca num posicionamento que ele é que sabe, ele é que manda, e ninguém pode questioná-lo. (Paula)

Na perspectiva comentada, o professor como centro do processo pedagógico é quem vai possibilitar a passagem dos seus alunos de um estado de não-crítica, não-cidadania, não-reflexão, a um estado que contém essas dimensões. Ensinar, por essa ótica "bancária" de educação, é transferir conhecimentos. Formar e educar o jovem, a criança, é dar formato a algo indeciso, acomodado, sem forma (Freire, 1996, p. 23-28).

Parafraseando Dagnino, e a partir da sua concepção de cidadania, temos instituições democráticas funcionando de modo autoritário. Ao contrário disso, a construção e consolidação de uma sociedade democrática pressuporia a eliminação do autoritarismo social que preside as relações sociais. Esse autoritarismo se materializaria, por exemplo, na noção e nas práticas que classificam as pessoas segundo critérios de gênero, classe, raça, dispondo-as nos seus “respectivos lugares sociais". "É visível no nosso cotidiano até fisicamente: é o elevador de serviço, a cozinha é lugar de mulher, cada macaco no seu galho etc." (Dagnino, 1994, p. 104), e na fala supracitada.

A despeito de um atual processo teórico-prático de construção de uma nova cidadania, atravessado por leituras e atuações políticas dos movimentos sociais -

ações que buscam intervir e transformar relações sociais estabelecidas que, pressuponho, constituem situações de desigualdade de toda ordem. Inspiro-me, para esse entendimento, em Fischer (1999) feministas, homossexuais, sem-terra, ambientalistas etc. -, como apontam Dagnino (1994; Dagnino et al., 2000), Ribeiro (2002), Eggert (2002), parte dos professores de sociologia indica que cotidianamente opera com a perspectiva formal de cidadania, que se define centralmente pela consciência do indivíduo como "portador" de direitos e deveres. Essa situação pode ser em parte compreendida segundo alguns aspectos: o tempo em que estão no magistério indica que possivelmente não tiveram acesso aos estudos mais recentes sobre o assunto; a dificuldade que tiveram os entrevistados em comentar seus referenciais teóricos de formação universitária, e, quando o conseguiram, raramente citaram a sociologia, aponta para, se não um desconhecimento de questões de estudo fundamentais dessa ciência, ao menos a pouca importância que teve na sua formação.

Do ponto de vista dos movimentos sociais, a relação entre educação e cidadania tem sido reclamada na ótica da estratégia política. A busca centra-se na construção de noções de cidadania fora dos parâmetros aos quais estamos habituados. A educação e a escolarização, nesse cenário, tornam-se instrumentos para a compreensão crítica dos direitos e deveres estabelecidos na tentativa de fazerem valer socialmente suas definições de cidadania. Pois, como adverte Freire, ainda que o habitual seja um ensino bancário,

\footnotetext{
[...] o educando a ele submetido não está fadado a fenecer;

[...] o educando a ele sujeitado pode, não por causa do conteúdo cujo "conhecimento" lhe foi transferido, mas por causa do processo mesmo de aprender, dar a volta por cima e superar o autoritarismo e o erro epistemológico do “bancarismo". (Freire, 1996, p. 279-280)
}

Essa passagem lembra que não é só o conteúdo de ensino propriamente que dará conta da formação de uma pessoa com tendências cidadãs e críticas. Compartilhando essa posição, Arroyo (in Buffa, 1999) observa que argumentar a necessidade de escolarização para o exercício da cidadania ignora práticas sociais mais amplas como formadoras dessas dimensões, bem como justifica a exclusão de grupos sociais 
daquele exercício, tendo em vista que essa perspectiva sublinha a ausência de preparo das pessoas para tal. Essa postura constitui a tese da imaturidade e da incapacidade de discernimento de camadas populares para a participação política, como bem assinala o autor, que justificou e justifica na história do pensamento e da prática política a exclusão da cidadania e da participação política.

Justificar a sociologia em virtude da formação para a crítica e para a cidadania pressupõe preparar os jovens para "um depois"; eles precisam aprender certos conteúdos para um dia exercer essas condições. E a escola não faz parte da trama social atual? Nela não se exerce a crítica e a cidadania? Argumentar a importância do conhecimento sociológico segundo aquele horizonte pode negar aos jovens a participação política; protela-se essa possibilidade em vista dos seus "desinteresses, descompromissos, apatias", como frequientemente são caracterizados por professores.

A sociologia é também associada à formação para a crítica, como venho referindo. Esta enquanto um posicionamento frente à realidade social tendo como horizonte a transformação social, a mudança de um ordem instituída. As idéias de crítica, cidadania e consciência parecem supor, conjuntamente, mudança. Desse modo, a sociologia é imediatamente vinculada à transformação social e pessoal. Essa noção pode ser percebida em algumas entrevistas:

[...] a sociologia é... ajuda a gente a ver a realidade com outros olhos, a sair do senso comum, a ter um olhar crítico sobre o senso comum, sobre o que não é comprovado cientificamente. (Cleonice)

[...] a sociologia vai servir para o pensamento, para a crítica, formação de questionamentos, de posicionamentos. (Paula)

Interessante relembrar aqui a observação de Maciel (1986) de que o tema cidadania e democracia reaparecem fortemente no contexto de redemocratização política do país desde fins da década de 1970. Nas entrevistas realizadas, vários professores relem- braram a ditadura militar no Brasil e, ao que parece, essa é a origem dos seus ideais de transformação social. Mesmo aqueles que não vivenciaram esse período da história, fixam nele um marco político que divide o país em um momento quando não se podia falar, questionar, reclamar da ordem instituída, e em um outro, atual, quando é preciso aprender a formar pensamentos e questionamentos. Uma professora que estudara pedagogia à época, relata: “[...] nós éramos proibidas de pensar sobre a sociedade, os problemas da sociedade, nós não podíamos pensar, a minha geração, em função da revolução de 64, ditadura militar" (Paula).

Na visão de Sacristán (1996, p. 53), independente do contexto histórico:

\section{[...] em educação sobrevive, em grande medida, uma forma de entender a mudança social que se nutre de um certo messianismo e da mentalidade burocrática tradicional. Isso consiste em atribuir ao discurso que se difunde uma força capaz de transformar a prática, um discurso cuja realização se tornará realidade pela própria força da evidência de suas virtudes e através da intervenção administrativa.}

A persistência na crença da relação positiva entre a sociologia, a crítica e a cidadania, mantém-se pela influência histórica das décadas de 1970 e de 1980 no Brasil, e também parece ser estimulada pelos textos legais que hoje regem o ensino. De um modo geral, os entrevistados dizem estar a par da situação legal da sociologia e teceram comentários favoráveis ao teor da LDB e dos PCNEM, no que se refere ao lugar da disciplina na promoção da consciência crítica e da cidadania. Dizem eles:

Olha, eu conheço a LDB, mas especificamente a sociologia... eu conheço as ciências humanas, a história, a geografia, a filosofia, a sociologia, o embasamento teórico que é preparar o cidadão para ser ativo na sociedade, na vida. (Flávia)

[os PCNEM] são um ótimo referencial bibliográfico para o estudo da filosofia e da sociologia. Eles têm um 
embasamento teórico invejável, crítico. Só que os problemas são muito ambíguos, eles são planejados verticalmente. Até eles chegarem acontecer... (Décio)

Essa última fala ressalta uma dimensão importante na proposição de reformas no ensino. "Planejados verticalmente", "até eles chegarem acontecer" denota o distanciamento da reflexão e da construção das propostas atuais daqueles que efetivamente têm a possibilidade de concretizá-las no espaço escolar. Em que pesem o "embasamento teórico invejável" e a eventual contemplação de tópicos, idéias, objetivos que correspondem a anseios de parte do professorado, na sua origem as propostas não honram ser um documento discutido e definido com a "participação da pluralidade de vozes que necessariamente deveria estar presente num processo conflitivo e contestado como é o do estabelecimento de um 'currículo nacional'” (Silva \& Gentili, 1996, p. 107). ${ }^{10}$

De modo geral, os comentários dos professores reproduzem não somente o discurso das reformas no ensino, como as expectativas sociais recorrentes em torno da sociologia. De uma perspectiva histórica, porém, compreende-se que essa ciência foi proposta e serviu a diferentes interesses nem sempre comprometidos com o enfrentamento radical da realidade social. Se recordarmos, como o faz Martins (1994), suas origens enquanto ciência com Saint-Simon, Auguste Comte e Émile Durkheim, sua função “seria detectar e buscar soluções para os 'problemas sociais', restaurando a 'normalidade social' e se convertendo dessa forma numa técnica de controle social e de manutenção do poder vigente" (p. 50).

Comumente, pensa-se na crítica como um argumento desfavorável a algum assunto. Proceder à apreciação negativa sobre algo, procurar somente as im-

${ }^{10}$ Essa idéia é parte de uma análise realizada pela Faculdade de Educação da Universidade Federal do Rio Grande do Sul sobre o documento "Parâmetros Curriculares Nacionais", do Ministério da Educação. Não há nominalmente a indicação do grupo de professores que a escreveu. Ver Silva e Gentili (1996). perfeições e faltas são características desse tipo de crítica. Ou ainda, reduzi-la ao conhecimento de uma multiplicidade de opiniões a respeito de um assunto. Duas professoras assim dizem quando percebem que seus alunos estão se tornando críticos:

\section{[...] simplesmente pelo fato quando ele resolve opinar. Para \\ mim já é desenvolvimento da crítica. (Luíza)}

[...] quando ele consegue defender as idéias dele. Quando ele busca argumentar o que ele pensa. (Amanda)

A sociologia, seus conteúdos, métodos e reflexões propiciariam meios de construir essa transformação do pensamento, alimentá-la e direcioná-la. Os referenciais teóricos utilizados, o tipo de formação que têm os licenciados e a prática em sala de aula anunciariam a feição da sociologia que efetivamente se tem no ensino médio e as suas virtualidades na formação dos estudantes. Esse é o sentido que dá Paulo Freire (Freire \& Shor, 1986) à educação enquanto instrumento de transformação da sociedade. Quando questionado por Ira Shor sobre o que aprendera no exílio a respeito de educação e do golpe militar de 1964, Freire diz que teve uma boa lição sobre os limites globais da educação. Entretanto, acrescenta, é por meio da educação que se pode "compreender o que é o poder na sociedade, iluminando as relações de poder que a classe dominante torna obscuras. Também podemos preparar e participar de programas para mudar a sociedade" (idem, p. 44).

Mas não é somente por meio de conteúdos que se consegue desvelar as relações sociais e de poder. O tipo de texto e o autor lidos, que inspiram e direcionam a análise da realidade, proporcionam isso, pelo menos em parte. Não obstante, um peso importante tem o exemplo vivo da ação política do professor. Sua atuação política dentro ou fora da escola parece estimular o próprio trabalho docente e às expectativas dos estudantes quanto às suas possibilidades de modificar algumas situações sociais. Um professor assim comenta o desdobramento que acredita ter sua ação política na sala de aula: 
[...] fui secretário da associação comunitária do meu bairro, sou sócio do CPERG, sou sócio do SINPRO. ${ }^{11}$ Participo de todas as greves desde 1980. Porque eu acho que melhor exemplo que o professor pode dar ao seu estudante e futuro trabalhador é lutar pelos seus direitos. (Décio)

A complexidade do processo de formação de uma pessoa cidadã, crítica, democrática, enfim, de sua consciência política, confirma que esse processo certamente não se constrói puramente a partir de livros; a prática social dos professores alimenta suas concepções intelectuais, e vice-versa. Florestan Fernandes (1986), numa análise da formação política e o trabalho do docente, afirma que "a transformação não é produto do avanço na esfera da consciência e também não é produto de uma elaboração espontânea da realidade". Uma "transformação substantiva", diz o sociólogo, somente seria possível no encadeamento de uma "consciência da situação com a prática modificadora" (Fernandes, 1986, p. 36).

Contudo, quando impera aquele raciocínio "messiânico" do qual fala Sacristán (1996), a crítica e a cidadania apresentam-se constituídas pela sua dimensão conteudista, de depósito mesmo de informações e conhecimentos que conduziriam os jovens a uma formação daquele tipo. Ao que parece, tem sido esse, essencialmente, o fundamento da prática docente de professores de sociologia, uma vez que o potencial formador dessa ciência é explicado pelos seus conteúdos de ensino. Ainda que a própria ação docente em sala de aula possa ser vista como um tipo de militância, a ausência de práticas políticas dentro e sobre o espaço escolar por parte de professores e alunos, e a relação docente-discente que tem caracterizado o ensino, por exemplo, indicam a desvinculação entre ação e reflexão na idéia hegemônica de crítica e cidadania. Essa realidade aponta ora o ativismo, ora

${ }^{11}$ CPERGS: Centro de Professores do Estado do Rio Grande do Sul, uma organização de professores que trabalham em escolas estaduais. SINPRO: Sindicato de Professores do Estado do Rio Grande do Sul, uma instituição de professores de escolas privadas. o verbalismo dos professores. Segundo Freire (1987, p. 77): “Não há palavra verdadeira que não seja práxis. Daí dizer que a palavra verdadeira seja transformar o mundo". Essa palavra, essência do diálogo que nutre a educação problematizadora, somente pode ser verdadeira quando suas dimensões - ação e reflexão não são divorciadas. Numa perspectiva dialética, a crítica compreende um fenômeno não pela sua falta ou diversidade de posicionamentos a seu respeito, mas pelas múltiplas relações e determinações que o produzem (Fischer, 1999). Essa perspectiva é ilustrada por um entrevistado quando comenta sobre o que é o "olhar crítico" a ser desenvolvido pelos estudantes com o auxílio dos conhecimentos sociológicos:

\section{[...] olhar crítico é você observar a realidade de forma radi- \\ cal, isto é, ir a fundo nas questões, não se contentar com as primeiras aparências; é você olhar o mundo e a realidade de forma crítica, que é sobretudo um método. E também a gente tem que ver que todas as coisas nesse mundo não acontecem de forma isolada; elas se interligam. (Décio)}

O olhar crítico tem estreita relação com o que Freire (1996, p. 35) chama de "curiosidade epistemológica”, postura que o docente libertador deve assumir em si, e também como objetivo na sua ação pedagógica com os estudantes. Caracteriza-se como "inquietação indagadora, como inclinação ao desvelamento de algo, como pergunta verbalizada ou não, como procura de esclarecimento, como sinal de atenção que sugere alerta" (Freire, 1996, p. 39).

\section{Possíveis elementos que conformam as expectativas dos professores}

Dois elementos que se destacam nas falas como conformadores das expectativas docentes em torno da sociologia para a crítica e para a cidadania são, sem dúvida, as metodologias de aula e de avaliação. Acreditam os professores que uma aula de sociologia deve ser à base de debates, alunos sentados em círculos ou em grupos, ao invés de enfileirados, e trabalhos e pesquisas, em vez de provas. Dizem: 
[...] é em círculo a aula... sempre em círculo ou então em grupos, não dá para ter um atrás do outro. Em grupo, quando há apresentação de trabalhos, questionamentos ou debate. (Paula)

[...] em sociologia dificilmente faço prova. Eu até não vou mentir, eu fiz uma prova com eles. Cheguei na aula e falei: gente, hoje vai ter prova, vocês guardem o material, só para ver o que eles pegaram. (Amanda)

A forma como conduzem suas aulas realiza diferentes maneiras dos estudantes conduzirem o seu pensamento. E mudanças pequenas no cotidiano escolar, como as disposições das classes, a não-centralização das aulas na figura do professor, os trabalhos e pesquisas em grupos auxiliam a construção de práticas e concepções de ensino e aprendizagem consoantes com exercícios de fato críticos e cidadãos.

A despeito das intenções de um formato de aula que propicie a crítica - em razão dos círculos, dos debates - e a cidadania - também em virtude da possibilidade de participação dos alunos no andamento das aulas -, algumas falas denunciam concepções e práticas que se valem desses espaços meramente como instrumento para reconhecimento de conceitos tidos como básicos ou introdutórios à sociologia. Professores que dizem avaliar o aluno conforme sua atuação em todas as aulas e não acreditar que decorar conceitos "prove" que o aluno aprendeu, acabam por aplicar testes-surpresa a fim de, contraditoriamente, "ver o que eles pegaram" (Amanda). De outra parte, algumas falas indicam que há ações numa direção contrária a essa. Reflexões dialogadas em sala de aula, pesquisas de campo, análise de vídeos e músicas, reportagens jornalísticas como ponto de partida para a análise sociológica, avaliação da aprendizagem para além de provas objetivas, apontam para um modelo de educação que busca problematizar a existência social do ser humano. Para além das metodologias e dos conteúdos, em consonância com esses, há uma postura diferenciada de docentes e alunos com o conhecimento; as próprias relações pedagógicas em sala de aula e fora dela assentam-se em outras bases que não as do autoritarismo.
Um elemento da prática docente que possivelmente aponta para a persistência da concepção de educação nos moldes da transmissão-assimilação é a adoção de livro didático. Ele revela-se não somente um meio de estudo, às vezes o único, do professor sobre os conhecimentos sociológicos, mas também o instrumento a partir do qual se selecionam os conteúdos a serem trabalhos na disciplina. Juntamente com os livros didáticos, revistas e jornais compõem os conteúdos de aulas.

\section{[...] a gente se baseia aqui [no livro]. E aí eu uso esse livro aqui, que é o mais recente que veio para nós. E trabalho com revistas também, a Superinteressante, a Mundo Jovem. (Eliana)}

[...] a gente trabalha com um livro didático. Então, o que que eu fiz, eu dividi os conteúdos desse livro com o primeiro e segundo ano [do ensino médio]. A base [para definir conteúdos e aulas] é o livro. (Amanda)

Com efeito, a partir de algumas dessas situações, o conhecimento sociológico não tem sido produzido em sala de aula, apesar de a metodologia e de as formas de avaliação seguidamente sugerirem o contrário. Subjacente à postura de certas práticas docentes, persiste, ao que parece, o que Meksenas (1994, p. 19) identifica como duas tendências no ensino da sociologia: a conceitual-linear e a temática fragmentada. A primeira "caracteriza-se por um programa centrado em conceitos apreendidos de modo isolado, como entidades que por si só definiriam as partes das quais a sociedade se compõe" (Meksenas, 1994, p. 19), ao passo que a segunda abordagem identifica-se como "um curso temático, no qual, no lugar das palavraschaves, elenca-se uma série de temas considerados básicos - cujas partes, também somadas, originariam uma pretensa totalidade social" (idem, ibidem). O desdobramento disso para o estudante é a necessidade de memorizar conteúdos e conceitos, uma vez que a apreensão destes é feita desvinculada da realidade histórica que os produz. Concomitantemente, porém, convivem com essa tendência de educação práticas 
problematizadoras. E nesse ponto parecem localizarse as "brechas" que proporcionariam perceber os limites daquela tendência na aprendizagem e, de maneira mais ampla, as contradições sociais e das próprias relações escolares.

A observação de Meksenas (1994), entretanto, não procede apenas para os estudantes do ensino médio. A formação universitária também por vezes se dá nesses níveis. Em parte foi possível perceber isso quando alguns entrevistados comentaram sua formação universitária e seus referenciais teóricos:

[...] na realidade, as disciplinas que mais me marcaram tinham a ver muito com a parte mesmo de trabalho com a criança, mais voltada mesmo para a área do magistério, que seria psicologia... na realidade a minha habilitação foi na área da filosofia, psicologia e didática. [...] Sociologia, muito pouco. Sociologia eu faço um gancho mais com a filosofia. Eu trabalho muito com livros de auto-estima, livros do doutor Lair Ribeiro, Ruptura da mente, um outro livro que eu estou lendo e tiro pensamentos, e... Roberto Shinyashiki. Então eu parto sempre de um pensamento, então eu chamo de pensamento do dia, e geralmente está ligado ao assunto que a gente vai discutir. (Luíza)

[...] gosto muito de história política e econômica. Psicologia eu gosto muito. Porque eu lido muito com crianças e préadolescentes. Então, para a aprendizagem é essencial que tu saibas se mentalmente a criança está pronta ou não. (Flávia)

Os referenciais teóricos de formação e de orientação no trabalho dos docentes indicam que possivelmente há um ecletismo no trato com temas sociológicos. A preferência e a utilização de materiais, por exemplo, da psicologia e da psicopedagogia, e o uso de livros de auto-estima sugerem que a abordagem dos problemas sociais não se dá, necessariamente, pelo prisma sociológico. Meksenas (1994) percebe isso quando afirma corretamente que em grande parte das escolas não são os profissionais da área que lecionam sociologia. Outras concepções, portanto, que não a sociológica, sobressaem conforme a formação universitária do docente que ministra a disciplina.
A repercussão disso no ensino para os estudantes, possivelmente, é uma visão fragmentada e teoricamente confusa da própria sociologia. As formas de ver, analisar e significar o mundo, segundo um olhar sociológico, constituem-se a partir da aproximação de diferentes, e até mesmo divergentes concepções de mundo. Com efeito, é justamente nas contradições das concepções teóricas e práticas que há possibilidades de construção de análises críticas. Não obstante, como revelaram algumas entrevistas, o ensino por meio de materiais outros que não da sociologia, freqüentemente não se presta a análises, mas a uma miscelânea de mensagens de auto-ajuda, adoção de certas posturas, como, por exemplo, defesa da paz, aversão à violência, reconhecimento da difícil realidade do mundo do trabalho, sem compreendê-las como objetos de estudo sociológico. ${ }^{12}$

A par da recorrência de expressões como mudança, transformação e crítica nas vozes dos professores, seguidamente aparecem também idéias que sugerem adaptação a determinadas expectativas sociais. A necessidade de estudar para conseguir emprego, por exemplo, é freqüente. Essas duas funções atribuídas à educação escolarizada por vezes parecem ser contraditórias. No entanto, elas se interpenetram. Florestan Fernandes (1966) diz que a escola sempre é parte de um certo "conservantismo social e cultural", assim como conduz a "influências inovadoras". Não somente é necessário conservar valores, hábitos e pensamentos, a fim de perpetuar a existência humana socialmente, como preparar para as reais e vigentes condições de existência. Desse modo, a mudança de que tanto se fala, sobretudo em relação às potencialidades do ensino da sociologia, pode representar a atualização de hábitos, valores e pensamentos ao ritmo das transformações de outras instituições sociais.

Freire (in Freire \& Shor, 1986), por sua vez, per-

${ }^{12}$ Com toda ordem de dificuldade que essa postura implica, sobretudo para um trabalho didático com adolescentes e jovens, ao menos compreenderia a busca pelos fundamentos sociais de tais fenômenos devidamente colocados em seus contextos históricos. 
cebe a relação entre escola e transformação social a partir de diferentes níveis. A começar pela sala de aula, transformação não é uma questão de metodologia, mas do "estabelecimento de uma relação diferente com o conhecimento e com a sociedade" (idem, p. 48).

A educação não é, sozinha, a alavanca da transformação social, porque é sobre ela que se depositam expectativas sociais. Este é um real limite da sua atuação. No entanto, na perspectiva da educação e transformação libertadoras das quais fala Freire, o "estímulo à crítica que ultrapassa os muros da escola" (idem, ibidem) é um elemento imprescindível para denunciar e atuar contra a ideologia dominante. Para Freire, ideologia refere-se ao mascaramento da realidade e das causas dos problemas sociais a favor daqueles que detêm o poder. Cabe ao professor, na sua ótica, proceder a essa denúncia, buscando a razão de ser dos fatos. Nesse sentido, o referencial teórico do professor atua como um reforço ou não dessa ideologia dominante. Suas concepções de mundo e a respeito dos fenômenos sociais não são neutras e divorciadas da sua postura em sala de aula. Desse modo, as formas de avaliação e de metodologias de aula alternativas às formas tradicionais e com as quais estamos habitualmente acostumados, bem como a leitura de determinados autores e livros, não revelam por si sós um ensino orientado à criticidade e à transformação libertadora. Pois, assim como acredita Freire que nem toda aula expositiva é bancária, a realidade pode continuar obscura para os estudantes mesmo numa aula cujo formato é um debate ou uma pesquisa de campo. "A questão é o conteúdo e o dinamismo da aula, a abordagem do objeto a ser conhecido. Elas reorientam os estudantes para a sociedade de forma crítica? Estimulam seu pensamento crítico ou não?" (Freire, in Freire \& Shor, 1986, p. 54).

\section{As dificuldades no ensino da sociologia}

A desvalorização da sociologia pelos estudantes, demonstrada quanto esses não se empenham nas aulas e nos trabalhos da mesma forma com que se dedicam a outras matérias, e também a desvaloriza- ção pela escola, quanto essa lhe reserva pouco tempo na grade curricular, são com frequiência assinaladas:

Eu gostaria de trabalhar com eles mais filmes [...] mas eu não tenho tempo porque são apenas dois períodos de aula. (Paula)

Eles [os alunos] têm um certo preconceito contra algumas disciplinas, eles não dão tanta importância, talvez porque o aluno do ensino médio esteja preocupado com o vestibular e não tenha especificamente a prova de sociologia no vestibular. (Amanda)

A formação teórica como um empecilho para o desempenho docente na sociologia é referida diretamente por uma professora cujas áreas de origem são a história e a pedagogia: "Eu gostaria de ter mais embasamento teórico sobre isso" (Flávia).

Um entrevistado, ao comentar suas dificuldades, fala do despreparo dos estudantes para acompanhar as aulas: "Devido à falta de embasamento teórico dos alunos e à falta de material produzido especificamente para esse segmento, os alunos têm, às vezes, dificuldade para entender a linguagem sociológica, tanto do professor como dos textos" (Pedro).

Essa constatação, a exemplo da fala imediatamente anterior, tem origem na formação dos licenciados em ciências sociais. Como o retorno desses licenciados à escola é bastante recente, apesar da existência das licenciaturas, o preparo para a educação básica não era de fato uma preocupação real porque o espaço de trabalho não existia. Presentemente já se constata a ocorrência de disciplinas e cursos de extensão voltados especialmente para a preparação de docentes e para discussões sobre o tema.

As dificuldades maiores, entretanto, segundo apontam quase todos aos professores, ficam a cargo do público do ensino médio: os adolescentes e os jovens.

\footnotetext{
Vários professores falaram: "ah! porque eles [os alu-
} nos] não querem nada com nada, os alunos não querem nada com nada", essas coisas assim. (Cleonice) 
[...] pouca leitura dos alunos; alienação destes em relação às questões atuais, descontração demasiada, descompromisso. (Vera)

[...] eu acho que eles não valorizam [a sociologia] porque não cai no vestibular, em concurso, vestibular. Eles valorizam mais português, matemática, química, física. (Eliana)

[...] os alunos no geral não contribuem com coisas que enriquecem a aula, eles não procuram, não pesquisam além do que é exigido. (Rafaela)

Arroyo (2000) diz que em seus diálogos com professores percebe que estes vêem a infância, a adolescência e a juventude como apáticas e desmotivadas. Esse sentimento contribui para que se sintam desnecessários a seus alunos, pois não demonstram vontade, curiosidade e disposição para aprender suas lições. Entretanto, é preciso indagar: de onde vêm o desinteresse, a apatia, o descompromisso, a falta de vontade de estudar dos jovens de hoje? Para Arroyo, essa situação da infância e da juventude espelha não somente nosso fracasso enquanto educadores, mas da nossa civilização, da nossa cultura. Observa ele: creditar o não-interesse pela escola, pela sociologia, enfim, o fracasso escolar dos estudantes a eles mesmos, as suas desmotivações em estudar e aprender, desconsidera outras dimensões que determinam tanto o fazer pedagógico quanto a vontade de aprender.

Quando professores afirmam que os alunos não lêem, são descompromissados, que "não querem nada com nada”, de certa maneira não inocentam apenas a si mesmos como também a concepções e práticas arraigadas na cultura pedagógica. Colocar a culpa nos alunos pelo fracasso escolar, expresso na evasão, na repetência, e até mesmo nas dificuldades de ensino de uma disciplina, como escutei nas entrevistas, é um argumento que inocenta o Estado, a ordem social e suas políticas.

Nesse sentido, quando professores observam que os estudantes não se interessam pela sociologia, que, na “verdade", eles não se interessariam pelos estudos de modo geral, afastam a possibilidade de pensar o problema de uma perspectiva diferente: o que tem a escola que não desperta o interesse deles? De modo específico, o que tem a sociologia, como ela tem sido construída, para que a achem desnecessária?

Além disso, argumentar a importância da sociologia e, de maneira ampla, das ciências humanas, pautando-se numa pretensa precarização política dos jovens, ignora uma questão teórica apressadamente dada como resolvida. Que jovem é esse? Todo jovem é politicamente apático e desinteressado? É imprescindível ter em conta a impossibilidade de pensar juventude e adolescência de uma perspectiva homogênea e universal. Se é inevitável a percepção do arrefecimento da participação política, social e cultural de jovens, sobretudo se temos em mente o modelo do movimento estudantil dos anos de 1960, também é inegável que contemporaneamente o protagonismo juvenil se dá centralmente no âmbito cultural. Práticas musicais, como rap, funk, reggae, pagode, e práticas esportivas, como capoeira, skatismo, são espaços potenciais na construção da identidade juvenil; são espaços e possibilidades de os jovens estabelecerem relações de sociabilidade com comunidades de uma maneira que foge à definição tradicional de participação política (Spósito, in Spósito et al., 2002; Dayrell, 2003). São relações permeadas por posturas participativas, criativas, autônomas, solidárias, que implicam exercício crítico e cidadão. O engajamento de jovens em grupos e movimentos ambientalistas, étnicos, feministas, de combate a doenças e acidentes de trânsito, por exemplo, expressam novo modo de militância e interesse juvenil por questões sociais. Ainda assim, essa realidade é muitas vezes ignorada por um certo imaginário pedagógico e social que insiste em defini-los unicamente como individualistas, consumistas e politicamente apáticos.

\section{Considerações finais}

Neste momento é possível pontuar algumas questões gerais, embora não conclusivas, na realidade provocativas, para pensar a sociologia na formação escolar. Ao que parece, marcar a especificidade des- 
sa ciência pela formação crítica e cidadã, considerando que essas práticas não têm um sentido universal, tem ao menos três consequiências imediatas na constituição de representações a seu respeito. Uma é divorciar as ciências entre as que ensinam a pensar e as que ensinam a fazer. Com relação à primeira: por que a matemática e a química, por exemplo, geralmente não são localizadas como lugares do crítico e da cidadania? E será que a sociologia tem cumprido suas "promessas" de construir essas dimensões nos estudantes?

Outra conseqüência é associar a sociologia e o seu ensino diretamente à transformação social. Uma perspectiva histórica da origem e constituição da sociologia enquanto ciência revela claramente que nem sempre sua vocação teve esse horizonte. Uma infra-estrutura epistemológica proporcionada pelos conhecimentos sociológicos pode, certamente, sensibilizar o olhar para a compreensão e atuação sobre os fenômenos sociais. Pensar sobre e compreender o mundo social é importante para dar-se conta de situações de opressão, preconceito, injustiça, bem como visualizar outras possíveis; não significa, no entanto, mudança imediata e linear da realidade e da própria pessoa que a estuda e interpreta.

Um terceiro efeito refere-se a uma postura que ignora processos educativos que acontecem fora da escola como construtores da criticidade, da reflexão, da cidadania. Denota um entendimento restrito de educação ao ambiente escolar. E, nesse sentido, digase de passagem, a escola, de maneira geral, reproduz rituais e crenças que pouca relação têm com um ensino daquela natureza. Se os estudantes, muitas vezes, não têm nenhuma possibilidade de ação dentro da sua própria escola, porque seus interesses são vistos como incompatíveis com uma aprendizagem de fato, como vão exercer ação naquele sentido? Como se gesta a cidadania e a crítica nesse cenário? Exatamente nesse ponto os movimentos sociais têm muito a ensinar à escola. E é a percepção e a compreensão da dinâmica de ambientes refratários e impermeáveis ao questionamento que possibilitam, justamente, a construção de olhares diferenciados sobre o mundo.
KELLY CRISTINE CORRÊA DA SILVA MOTA, mestre em educação pela Universidade do Vale do Rio dos Sinos (UNISINOS), é professora de sociologia na Escola Estadual Farroupilha (Viamão, RS) e professora no curso de pedagogia nas Faculdades de Taquara (FACCAT, Taquara, RS). Publicou recentemente: A sociologia no ensino médio brasileiro e seus lugares na formação dos estudantes (Revista Educação Unisinos, São Leopoldo, RS, v. 7, n 13, 2003, p. 155-186); Reflexões sobre a sociologia no ensino médio (Informativo da ADUNISINOS - Associação dos Docentes da UNISINOS -, São Leopoldo, RS, n 29 , abril de 2003, p. 4-5) e A importância da sociologia na educação básica dos jovens (Mundo Jovem, PUC/RS, Porto Alegre, RS, fev. 2002,p. 10).E-mail: kellysociologia@pop.com.br

\section{Referências bibliográficas}

ARROYO, Miguel, (2000). Ofício de mestre: imagens e autoimagens. $3^{\mathrm{a}}$ ed. Petrópolis: Vozes.

, (1998). Trabalho, educação e teoria pedagógica. In: FRIGOTTO, Gaudêncio (org.). Educação e crise do trabalho: perspectivas de final de século. $2^{\text {a }}$ ed. Petrópolis: Vozes, p. $138-165$.

(org.) (1991). Da escola carente à escola possível. São Paulo: Loyola.

BUFFA, Ester, (org.) (1999). Educação e cidadania: quem educa o cidadão? São Paulo: Cortez.

CORRÊA, Lesi, (1993). A importância da disciplina sociologia no currículo de $2^{\circ}$ grau: a questão da cidadania. Dissertação de mestrado. Pontifícia Universidade Católica de São Paulo.

COSTA PINTO, Luiz de Aguiar, (1944). O ensino das ciências sociais no Brasil. Sociologia, São Paulo, vol. 6, nº 1.

DAGNINO, Evelina, (1994). Anos 90: política e sociedade no Brasil. São Paulo: Brasiliense.

DAGNINO, Evelina, ALVAREZ, Sônia, ESCOBAR, Arturo, (orgs.) (2000). Cultura e política nos movimentos sociais latino-americanos: novas leituras. Belo Horizonte: Ed. UFMG.

DAYRELL, Juarez, (2003). O jovem como sujeito social. Revista Brasileira de Educação, Rio de Janeiro: ANPEd, Campinas: Autores Associados, nº 24, set.-dez., p. 40-52.

EGGERT, Edla, (2002). Mulheres e cidadania: reflexões em torno da participação delas no orçamento participativo do estado do Rio Grande do Sul: Região do Vale do Caí entre 1999 e 2001 (mimeo.). 
FERNANDES, Florestan, (1986). A formação política e o trabalho do professor. In: CATANI, Denise Bárbara (org.). Universidade, escola e formação de professores. São Paulo: Brasiliense, p. 13-37.

, (1966). Educação e sociedade no Brasil. São Paulo: Dominus e Editora da USP.

FISCHER, Maria Clara Bueno, (1999). Um lugar para a educação numa prática sindical transformadora. Estudos Leopoldenses Série Educação, São Leopoldo, v. 3, nº 4, p. 21-37.

FREIRE, Paulo, (1996). Pedagogia da autonomia: saberes necessários à prática educativa. São Paulo: Paz e Terra. , (1987). Pedagogia do oprimido. $17^{\mathrm{a}}$ ed. Rio de Janeiro: Paz e Terra.

FREIRE, Paulo, SHOR, Ira, (1986). Medo e ousadia: o cotidiano do professor. $5^{\mathrm{a}}$ ed. Rio de Janeiro: Paz e Terra.

GADOTTI, Moacir, (2000). Perspectivas atuais da educação. Porto Alegre: Artes Médicas.

GENTILI, Pablo, (2000). Qual educação para qual cidadania? Reflexões sobre a formação do sujeito democrático. In: SEMINÁRIO INTERNACIONAL DE REESTRUTURAÇÃO CURRICULAR: Utopia e Democracia na Educação Cidadã. Porto Alegre: Editora UFRGS, p. 143-156.

GIGLIO, Adriano Carneiro, (1999). A sociologia na escola secundária: uma questão para as ciências sociais no Brasil anos 40 e 50. Dissertação de mestrado em Sociologia. Instituto Universitário de Pesquisa do Rio de Janeiro (IUPERJ).

MACIEL, Maria, (1986). Tendências das ciências sociais no Brasil: do autoritarismo à redemocratização. Brasília: UnB/SOL. Série Sociológica, $\mathrm{n}^{\circ} 60$.

MARTINS, Carlos Benedito, (1994). O que é sociologia? $38^{\mathrm{a}}$ ed. São Paulo: Brasiliense.
MEKSENAS, Paulo, (1995). O ensino da sociologia na escola secundária. Leituras e imagens, UDESC/FAED, jun., p. 67-79. , (1994). Sociologia. São Paulo: Cortez.

MEUCCI, Simone, (2000). A institucionalização da sociologia no Brasil: os primeiros manuais e cursos. Dissertação de mestrado em Sociologia. Universidade Estadual de Campinas.

MOTA, Kelly Cristine Corrêa da Silva, (2003). Os lugares da sociologia na formação escolar de jovens do ensino médio: formação ou exclusão da cidadania e da crítica? Dissertação de mestrado em Educação. Universidade do Vale do Rio dos Sinos.

RIBEIRO, Marlene, (2002). Educação para a cidadania: questão colocada pelos movimentos sociais (mimeo.).

SACRISTÁN, J. G., (1996). Reformas educacionais: utopia, retórica e prática. In: SILVA, Tomaz Tadeu da, GENTILI, Pablo (orgs.). Escola S.A.: quem perde e quem ganha no mercado educacional do neoliberalismo. Brasília: Confederação Nacional dos Trabalhadores na Educação (CNTE), p. 150-166.

SANTOS, Mário Bispo dos, (2002). A sociologia no contexto das reformas educacionais: um século de idas e vindas da sociologia no ensino médio (mimeo.).

SILVA, Tomaz Tadeu da, GENTILI, Pablo, (orgs.) (1996). Escola $S$. A.: quem perde e quem ganha no mercado educacional do neoliberalismo. Brasília: CNTE.

SPÓSITO, Marília, ABRAMO, Helena, FREITAS, Maria Virgínia de, (orgs.) (2002). Juventude em debate. $2^{\text {a }}$ ed. São Paulo: Cortez.

Recebido em outubro de 2003 Aprovado em setembro de 2004 


\section{Resumos/Abstracts}

Kelly Cristine Corrêa da Silva Mota

Os lugares da sociologia na formação de estudantes do ensino médio: as perspectivas de professores

Este trabalho apresenta resultados de uma pesquisa sobre o ensino da sociologia no ensino médio. O objetivo é compreender o lugar do conhecimento sociológico na formação escolar de estudantes desse nível de ensino, a partir de perspectivas de professores de sociologia. Leituras teóricas, leituras de documentos legais e entrevistas com professores indicaram os conhecimentos sociológicos como componentes fundamentais na formação de estudantes cidadãos e críticos. A problematização desse argumento, a partir de uma concepção ampliada de educação, cidadania e crítica apontou que o trabalho docente na área está pautado no pressuposto da escolarização e da precarização política dos jovens para o exercício da cidadania e da crítica. A sociologia ensinada nas escolas, percebida como elemento privilegiado na constituição dessas dimensões, acaba por sublinhar um pretenso despreparo, desinteresse e incapacidade política dos jovens para tal exercício. Além disso, ignora outras práticas e espaços sociais que conduzem o ser humano a uma formação crítica e cidadã.

Palavras-chave: ensino da sociologia; sociologia no ensino médio; cidadania e crítica.

The place of sociology in the formation of secondary school students: the teachers' perspective

This article presents the results of research on the teaching of sociology in secondary schools. Its purpose is to understand the place of sociological knowledge in the formation of secondary school students based on the perspective of teachers of sociology. Theoretical studies, the analysis of legal documents and interviews with teachers pointed to sociological knowledge as a fundamental component in the formation of critical students and citizens. The problematisation of this argument, starting from a broad critical conception of education and citizenship, suggests that teaching in this field is directed by the presupposition of schooling and the lack of preparation on the part of students to exercise citizenship critically. The sociology taught in schools, perceived as a privileged element in the constitution of these dimensions, ends up by underlining the young people's supposed lack of preparation, interest and political capacity for the exercise of this activity. In addition, it ignores other practices and social spaces which lead the human being to a critical formation for citizenship.

Key-words: teaching of sociology; sociology in secondary education; critical citizenship 